\title{
ANALISIS RISIKO KERJA PADA AREA HOT METAL TREATMENT PLANT DIVISI BLAST FURNACE DENGAN METODE HAZARD IDENTIFICATION AND RISK ASSESSMENT (HIRA)
}

\author{
Muhamad Bob Anthony \\ Program Studi Teknik Industri, Fakultas Teknik, Universitas Serang Raya \\ Email: tonipbmti@gmail.com
}

\begin{abstract}
Abstrak - Penelitian ini memiliki tujuan untuk mengetahui nilai risiko potensi bahaya kerja dan level risiko potensi bahaya kerja pada area produksi hot metal treatment plant divisi blast furnace yang saat ini dalam tahap commissioning. Penelitian ini menggunakan pendekatan dengan metode HIRA (Hazard Identification and Risk Assessment) untuk mengetahui nilai risiko potensi bahaya kerja dan level risiko potensi bahaya kerja. Hasil yang didapatkan dengan menggunakan HIRA (Hazard Identification and Risk Assessment) didapatkan sebanyak 26 risiko yang digolongkan berdasarkan potensi bahaya yaitu 9 risiko termasuk dalam kategori high $(H), 7$ risiko kategori moderate $(M)$ dan sisanya sebanyak 10 risiko termasuk dalam kategori low (L). Rekomendasi yang dapat diberikan adalah dengan melakukan mitigasi secara terperinci terhadap risiko kategori high $(H)$ dan kategori moderate $(M)$ sampai level risiko tersebut turun menjadi risiko kategori low (L) sebelum plant blast furnace dioperasikan secara penuh.
\end{abstract}

Kata kunci: Blast Furnace, Hazard Identification and Risk Assessment, Risiko

\begin{abstract}
This study aims to determine the value of the risk of work hazard potential and the level of risk of potential occupational hazards in the blast furnace division of hot metal treatment plant which is currently in the commissioning stage. This study uses an approach with the HIRA (Hazard Identification and Risk Assessment) method to determine the value of the risk of potential occupational hazards and the level of risk of potential occupational hazards. The results obtained by using HIRA (Hazard Identification and Risk Assessment) obtained 26 risks classified by potential hazards, namely nine risks included in the high category $(H)$, seven risks moderate category $(M)$ and the remaining ten risks involved in the low category $(L)$. The recommendation that can give is to carry out detailed mitigation of the risk of high $(H)$ and moderate $(M)$ categories until the risk level falls to the risk of the low (L) category before the blast furnace plant is fully operating.
\end{abstract}

Keywords: Blast Furnace, Hazard Identification and Risk Assessment, Risk

\section{PENDAHULUAN}

Industri baja merupakan industri strategis yang menghasilkan bahan baku penting bagi industri-industri secara keseluruhan baik untuk infrastruktur (pembangunan gedung, jalan, jembatan, jaringan listrik dan telekomunikasi), produksi barang modal (mesin pabrik dan material pendukung serta suku cadangnya), alat transportasi (kapal laut, kereta api dan rel), otomotif hingga persenjataan.

Tuntutan ganti rugi merupakan konsentrasi logis dari sebuah kecelakaan atau insiden seiring dengan berkembangnya pengawasan di bidang Keselamatan dan Kesehatan Kerja (K3) dan semakin ketatnya pelaksanaan hukum sehingga tuntutan terhadap tersedianya tempat kerja yang aman, sehat dan tidak merusak lingkungan semakin besar juga.

Pemerintah Indonesia mulai berkomitmen menjaga keselamatan ke tenaga kerja dengan dibentuknya Undang - Undang No.1 Tahun 1970 tentang Keselamatan Kerja. Selain itu, terdapat juga Undang - Undang No.13 Tahun 2003 tentang Ketenagakerjaan. Pada pasal 86 disebutkan bahwa setiap pekerja atau buruh mempunyai hak untuk memperoleh perlindungan atas keselamatan dan kesehatan kerja. Hal ini bertujuan untuk mewujudkan produktivitas kerja yang optimal. Untuk mewujudkannya, pada pasal 87 disebutkan bahwa setiap perusahaan wajib menerapkan sistem manajemen keselamatan dan kesehatan kerja yang terintegrasi dengan sistem manajemen perusahaan dalam upaya mengelola risiko yang ada dalam kegiatan 
perusahaan yang memungkinkan terjadinya cidera pada manusia, gangguan maupun pada perusahaan (Supriyadi \& Ramdan, 2017).

Sasaran utama program K3 adalah mengelola risiko untuk mencegah terjadinya kecelakaan atau kejadian yang tidak diinginkan melalui proses identifikasi bahaya, penilaian risiko dan pengendaliannya. Identifikasi bahaya dapat mengurangi peluang terjadinya kecelakaan karena identifikasi bahaya berkaitan dengan faktor penyebab kecelakaan (Restuputri \& Sari, 2015). Dengan melakukan identifikasi bahaya maka sumber-sumber bahaya dapat diketahui sehingga kemungkinan kecelakaan dapat ditekan (Ramli, 2010).

Hazard Identification and Risk Assessment (HIRA) merupakan salah satu metode identifikasi kecelakaan kerja dengan penilaian risiko sebagai salah satu poin penting untuk mengimplementasikan Sistem Manajemen Keselamatan dan Kesehatan Kerja (SMK3) (Panjaitan, 2017; Sulaksmono, 1997). Penggunaan metode HIRA dari beberapa penelitian yang terdahulu sudah terbukti mampu mengidentifikasi dan menurunkan faktor risiko yang terjadi dalam aktivitas kerja (Alauddin, Denny, \& Jayanti, 2015; Ambarani \& Tualeka, 2017; Kurniawati, Sugiono, \& Yuniarti, 2014; Suryanti \& Mulyono, 2017).

PT KRS adalah salah satu produsen besar produk baja terpadu kualitas tinggi di Indonesia dengan produk utamanya adalah baja lembaran panas, baja lembaran dingin dan batang kawat. Sumber daya alam yang digunakan sebagai bahan baku dalam industri baja adalah bijih besi dan pasir besi. Namun karena ketersediaan akan sumber daya alam yang semakin menipis dan harganya yang cenderung meningkat jika harus terus dilakukan impor, maka PT KRS bekerja sama dengan sebuah perusahaan multinasional besar membangun sebuah pabrik blast furnace complex.

Blast furnace digunakan untuk mereduksi secara kimia dan mengkonversi secara fisik bijih besi yang padat menjadi logam besi yang panas (hot metal). Bahan baku yang dimasukkan pada blast furnace adalah bijih besi, kokas dan batu kapur yang diumpan dari atas. Sampai saat ini pabrik blast furnace masih dalam tahap commissioning. Commissioning adalah proses sistematik untuk memastikan bahwa seluruh sistem yang ada di bangunan berjalan sesuai dengan perencanaan di awal (U.S. Department of Energy). Dengan adanya pelaksanaan commissioning ini akan didapatkan kepastian hasil suatu pekerjaan. Penelitian ini mengidentifikasi potensi-potensi bahaya yang terdapat di PT. KRS untuk dinilai besarnya peluang terjadinya suatu kecelakaan atau kerugian selama tahap commisioning dengan menggunakan metode HIRA

\section{METODE PENELITIAN}

Objek penelitian ini adalah Standard Operating Prosedur (SOP) yang terdapat dalam proses kerja pada area produksi di hot metal treatment plant divisi blast furnace PT. KRS. Data yang diambil adalah data laporan perusahaan divisi blast furnace dan pengamatan di lapangan dilakukan dari tanggal 01 Mei 2018 hingga 31 Juli 2018.

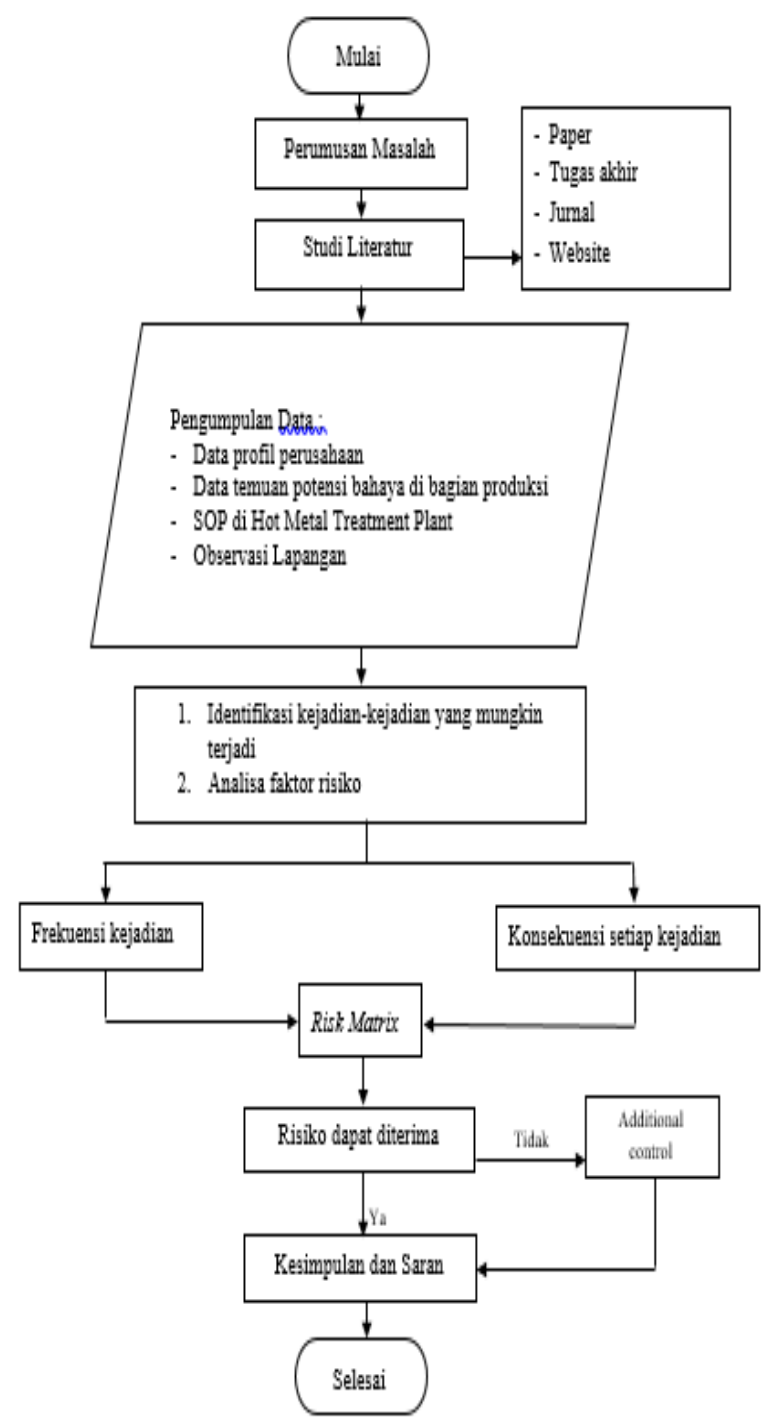

Gambar 1. Diagram alir penelitian

Data yang diperoleh dalam penelitian ini bersumber dari data primer maupun sekunder. Data primer diperoleh melalui observasi lapangan, wawancara serta melakukan diskusi dengan karyawan di PT. KRS area produksi di 
hot metal treatment plant divisi blast furnace untuk mendapatkan hasil mengenai kemungkinan dan dampak risiko Keselamatan dan Kesehatan Kerja (K3). Data sekunder di diperoleh dari dokumen-dokumen serta catatancatatan perusahaan yang berhubungan dengan masalah yang diteliti dan Keselamatan dan Kesehatan Kerja (K3) serta dari sumber atau data lain sebagai pelengkap penelitian ini.

\section{HASIL DAN PEMBAHASAN}

Pengolahan data dilakukan dengan menggunakan metode hazard identification and risk assessment (HIRA) dan matriks risiko PT. KRS. Proses identifikasi menggunakan HIRA adalah identifikasi bahaya, analisa risiko dan menetapkan tindakan pengendalian Ada dua kriteria penting untuk mengukur risiko yaitu :

1. Kemungkinan atau peluang (probability)

Probability merupakan suatu kemungkinan terjadinya suatu kecelakaan atau kerugian ketika dihadapkan dengan suatu bahaya. Contoh dari kemungkinan (probability) adalah peluang orang jatuh ketika melewati jalan licin, peluang tersengat listrik, peluang menabrak dan lain lain (Tabel 1).

2. Dampak atau akibat (consequence)

Consequence merupakan suatu tingkat keparahan atau kerugian yang mungkin terjadi dari suatu kecelakaan karena bahaya yang ada. Hal ini bisa terkait dengan manusia, properti, lingkungan dan lain - lain. Contoh dari dampak (consequence) adalah kematian, cacat dan lain lain (Tabel 2)

Ukuran gabungan likelihood dan dampak atau level risiko diperoleh berdasarkan perkalian level likelihood dengan dampak. Level risiko tertinggi bernilai $25(5 \times 5)$ sedangkan level risiko terendah bernilai 1 (1x1) (Tabel 3).

Tabel 1. Likelihood

\begin{tabular}{cll}
\hline No. & \multicolumn{1}{c}{ Kategori } & \multicolumn{1}{c}{ Penjelasan } \\
\hline 1 & Nyaris tidak mungkin (Rare) & Hanya terjadi pada kondisi sangat khusus \\
2 & Jarang (Unlikely) & Bisa saja terjadi waktu tertentu \\
3 & Mungkin (Possible) & Mungkin terjadi sewaktu-waktu \\
4 & Sering (Likely) & Akan mungkin sering terjadi \\
5 & Hampir pasti (Almost certain) & Hampir pasti terjadi \\
\hline
\end{tabular}

Tabel 2. Consequence

\begin{tabular}{|c|c|c|}
\hline No. & Kategori & Penjelasan \\
\hline 1 & Tak berakibat apapun & P3K, Polusi < 100 Itr, Kerugian < US \$ 1000 \\
\hline 2 & Ringan (Minor) & $\begin{array}{l}\text { Butuh layanan medis, Polusi } 100 \mathrm{ltr}-1 \mathrm{~m}^{3} \text {, Kerugian } \\
\text { US } \$ 1000-10.000\end{array}$ \\
\hline 3 & Sedang (Moderate) & $\begin{array}{l}\text { hari kerja hilang, Polusi } 1-10 \mathrm{~m}^{3} \text {, Kerugian US } \$ \\
10.000-100.000\end{array}$ \\
\hline 4 & Major (Berat) & $\begin{array}{l}\text { Cacat/fatal, Polusi } 10-100 \mathrm{~m}^{3} \text {, Kerugian US } \$ \\
100.000-1 \text { Million }\end{array}$ \\
\hline 5 & Katastropi & $\begin{array}{l}\text { Fatal lebih dari satu, Polusi > } 100 \mathrm{~m}^{3} \text {, Kerugian > } \\
\text { US } \$ 1 \text { Million }\end{array}$ \\
\hline
\end{tabular}


Tabel 3. Risk Matrix

\begin{tabular}{|l|c|c|c|c|c|}
\hline \multirow{2}{*}{ Likelihood } & \multicolumn{5}{|c|}{ Consequences } \\
\cline { 2 - 6 } & Insignificant & Minor & Moderate & Major & Catastrophic \\
\hline A (Almost certain) & H & 2 & 3 & 4 & 5 \\
\hline B (Likely) & M & H & H & E & E \\
\hline C (Moderate) & L & M & H & E & E \\
\hline D (Unlikely) & L & L & M & H & E \\
\hline E (Rate) & L & L & M & H & H \\
\hline
\end{tabular}

Level risiko dikelompokkan menjadi 4 (empat), yaitu:

1. Risiko Ekstrim (extreme) : nilai $>15$ hingga 25

2. Risiko Tinggi (high) : nilai $>10$ hingga 15

3. Risiko Sedang (moderate) : nilai $>5$ hingga 10

4. Risiko Rendah (low) : nilai 1 hingga 5

Risiko dikatakan memiliki tingkat yang dapat diterima bila :

1. Level risiko rendah sehingga tidak perlu penanganan khusus

2. Tidak tersedia penanganan untuk risiko

3. Biaya penanganan termasuk biaya asuransi lebih tinggi dari manfaat yang diperoleh bila risiko tersebut diterima

4. Peluang dari adanya risiko tersebut lebih besar dari ancamannya

5. Risiko yang terjadi tidak mempengaruhi dari pencapaian tujuan perusahaan

Identifikasi risiko pada area hot metal treatment plant terbagi dari beberapa bagian aktivitas seperti proses charging material menuju storage bin, proses pergantian impeller, proses hot impeller, dan proses operasi manual temperature dan sampling device. Kemungkinan risiko yang terjadi pada proses charging material menuju storage bin antara lain pendarahan, luka memar, iritasi mata, sesak nafas, keracunan dan pingsan. Potensi risiko yang terjadi pada aktivitas proses pergantian impeller antara lain cedera, dehidrasi, iritasi mata, sesak napas, luka memar maupun luka terbakar. Bahaya yang terjadi pada proses hot repair impeller adalah radiasi panas, terkena hot impeller, debu dan pekerja terjatuh dari exchange car. Proses cleaning impeller head mempunyai potensi risiko seperti tangan melepuh, luka bakar ringan, iritasi mata, sesak napas, dan cedera. Risiko yang mungkin terjadi pada aktivitas proses operasi manual temperature dan sampling device antara lain tangan terbakar, luka bakar ringan, cedera, dehidrasi, terjatuh, tersetrum, tersandung dan memar. (Tabel 4). Hasil identifikasi risiko kemudian dianalisis dengan menggunakan metode hazard identification and risk assessment (HIRA) (Tabel 5).

Berdasarkan hasil identifikasi risiko kecelakaan kerja yang dapat terjadi di area produksi hot metal treatment plant diperoleh 26 risiko yang digolongkan berdasarkan potensi bahaya yaitu 9 risiko masuk dalam kategori high $(\mathrm{H}), 7$ risiko masuk dalam kategori moderate (M) dan sisanya sebanyak 10 risiko masuk dalam kategori low (L).

Beberapa rekomendasi untuk mengurangi risiko pada kategori hgh antara lain inspeksi atau pengawasan berkala, safety talk, penggunaan APD, safety sign, mematuhi rambu-rambu safety serta penyediaan air minum yang cukup. Rekomendasi risiko yang termasuk dalam kategori moderat antara lain inspeksi atau pengawasan berkala, safety talk, penggunaan APD, pengawasan penggunaan masker, safety sign, dan mematuhi rambu-rambu safety. 
Tabel 4. Hasil Identifikasi Risiko

\begin{tabular}{|c|c|c|c|}
\hline No & Aktivitas & Bahaya & Risiko \\
\hline 1 & $\begin{array}{lc}\text { Proses } & \text { charging } \\
\text { material } & \text { menuju } \\
\text { storage bin } & \end{array}$ & $\begin{array}{l}\text { Tergores pisau charging } \\
\text { Kejatuhan material } \\
\text { Debu } \\
\text { Terpeleset akibat lantai kerja licin } \\
\text { Kabel sling putus } \\
\text { Terkena swing } \\
\text { Paparan gas }\end{array}$ & $\begin{array}{l}\text { Pendarahan } \\
\text { Luka memar, pendarahan } \\
\text { Iritasi mata, sesak nafas } \\
\text { Luka, terjatuh } \\
\text { Tertimpa pekerja } \\
\text { Cedera, luka memar } \\
\text { Keracunan, pingsan }\end{array}$ \\
\hline 2 & $\begin{array}{l}\text { Proses } \\
\text { impeller }\end{array}$ & $\begin{array}{l}\text { Radiasi panas } \\
\text { Pekerja terjatuh } \\
\text { Debu } \\
\text { Tangan terjepit } \\
\text { Pekerja tersandung benda lain } \\
\text { Kabel yang menghalangi mobilisasi }\end{array}$ & $\begin{array}{l}\text { Cedera, dehidrasi } \\
\text { Cedera, luka } \\
\text { Iritasi mata, sesak nafas } \\
\text { Luka memar, luka gores } \\
\text { Terjatuh, cedera } \\
\text { Tersandung, memar }\end{array}$ \\
\hline 3 & $\begin{array}{l}\text { Proses hot repair } \\
\text { impeller }\end{array}$ & $\begin{array}{l}\text { Radiasi panas } \\
\text { Terkena hot impeller } \\
\text { Debu } \\
\text { Pekerja terjatuh dari exchange car }\end{array}$ & $\begin{array}{l}\text { Cedera, dehidrasi, luka bakar } \\
\text { Tangan melepuh, luka bakar } \\
\text { ringan } \\
\text { Iritasi mata, sesak nafas } \\
\text { Cedera }\end{array}$ \\
\hline 4 & $\begin{array}{l}\text { Proses cleaning } \\
\text { impeller head }\end{array}$ & $\begin{array}{l}\text { Terkena percikan hot metal } \\
\text { Debu } \\
\text { Pekerja terkena benda lain }\end{array}$ & $\begin{array}{l}\text { Tangan melepuh, luka bakar } \\
\text { ringan } \\
\text { Iritasi mata, sesak nafas } \\
\text { Cedera }\end{array}$ \\
\hline 5 & $\begin{array}{l}\text { Proses operasi manual } \\
\text { temperature dan } \\
\text { sampling device }\end{array}$ & $\begin{array}{l}\text { Terkena percikan hot metal } \\
\text { Debu } \\
\text { Pekerja terkena benda lain } \\
\text { Terpeleset akibat lantai licin } \\
\text { Aliran listrik } \\
\text { Kabel yang menghalangi mobilisasi }\end{array}$ & $\begin{array}{l}\text { Tangan melepuh, luka bakar } \\
\text { ringan } \\
\text { Iritasi mata, sesak nafas } \\
\text { Cedera } \\
\text { Luka, terjatuh } \\
\text { Kesetrum } \\
\text { Tersandung, memar }\end{array}$ \\
\hline
\end{tabular}

Tabel 5. Hazard Identification and Risk Assessment (HIRA)

\begin{tabular}{|c|c|c|c|c|c|c|c|c|c|c|c|c|}
\hline No & Aktivitas & Bahaya & Resiko & Acuan & Existing Control & $\mathrm{L}$ & $\mathrm{C}$ & $\mathrm{R}$ & Additional Control & $\mathrm{L}$ & $\mathrm{C}$ & $\mathrm{R}$ \\
\hline \multirow[t]{7}{*}{1} & \multirow{7}{*}{$\begin{array}{l}\text { Proses } \\
\text { charging } \\
\text { material } \\
\text { menuju } \\
\text { storage bin }\end{array}$} & $\begin{array}{l}\text { Tergores pisau } \\
\text { charging }\end{array}$ & Pendarahan & $\begin{array}{c}\text { SOP } \\
3133 \mathrm{BF} 33302\end{array}$ & $\begin{array}{l}\text { Menggunakan } \\
\text { metode kerja, APD } \\
\text { (sarung tangan) }\end{array}$ & 2 & 2 & $\mathrm{~L}$ & & & & \\
\hline & & $\begin{array}{l}\text { Kejatuhan } \\
\text { material }\end{array}$ & $\begin{array}{l}\text { Luka memar, } \\
\text { pendarahan }\end{array}$ & $\begin{array}{c}\text { SOP } \\
3133 \text { BF33 } 302\end{array}$ & $\begin{array}{l}\text { Menggunakan } \\
\text { metode kerja dan } \\
\text { APD }\end{array}$ & 2 & 2 & L & & & & \\
\hline & & Debu & $\begin{array}{l}\text { Iritasi mata, } \\
\text { sesak nafas }\end{array}$ & $\begin{array}{c}\text { SOP } \\
3133 \text { BF33 } 302\end{array}$ & $\begin{array}{l}\text { Awareness } \mathrm{K} 3 \text {, } \\
\mathrm{APD} \text { (respirator } \\
\text { dan masker) }\end{array}$ & 3 & 2 & $\mathrm{M}$ & $\begin{array}{l}\text { Inspeksi/pengawasan } \\
\mathrm{K} 3 \text { secara berkala, } \\
\text { pengawasan } \\
\text { penggunaan masker }\end{array}$ & 3 & 1 & $\mathrm{~L}$ \\
\hline & & $\begin{array}{l}\text { Terpeleset } \\
\text { akibat licinnya } \\
\text { lantai kerja }\end{array}$ & Luka, terjatuh & $\begin{array}{c}\text { SOP } \\
3133 \text { BF33 } 302\end{array}$ & $\begin{array}{l}\text { Eliminasi } \\
\text { (membersihkan } \\
\text { area kerja) }\end{array}$ & 2 & 2 & $\mathrm{~L}$ & & & & \\
\hline & & $\begin{array}{l}\text { Kabel sling } \\
\text { putus }\end{array}$ & $\begin{array}{l}\text { Tertimpa } \\
\text { pekerja }\end{array}$ & $\begin{array}{c}\text { SOP } \\
3133 \text { BF33 } 302\end{array}$ & $\begin{array}{l}\text { Pengendalian } \\
\text { teknis (pemberian } \\
\text { rambu-rambu } \\
\text { peringatan) }\end{array}$ & 3 & 3 & $\mathrm{H}$ & $\begin{array}{l}\text { Inspeksi/pengawasan } \\
\mathrm{K} 3 \text { secara berkala, } \\
\text { safety talks, APD }\end{array}$ & 3 & 2 & M \\
\hline & & Terkena swing & $\begin{array}{l}\text { Cedera, luka } \\
\text { memar }\end{array}$ & $\begin{array}{c}\text { SOP } \\
3133 \text { BF33 } 302\end{array}$ & $\begin{array}{l}\text { Pengendalian } \\
\text { teknis (pemberian } \\
\text { rambu-rambu } \\
\text { peringatan) }\end{array}$ & 2 & 3 & M & $\begin{array}{l}\text { Inspeksi/pengawasan } \\
\mathrm{K} 3 \text { secara berkala, } \\
\text { safety talks, APD }\end{array}$ & 2 & 2 & $\mathrm{~L}$ \\
\hline & & Paparan gas & $\begin{array}{l}\text { Keracunan, } \\
\text { pingsan }\end{array}$ & $\begin{array}{l}\text { Kepmenaker. } \\
\text { 187/MEN/1999 }\end{array}$ & $\begin{array}{l}\text { Gas detector, } \\
\text { menggunakan } \\
\text { metode kerja }\end{array}$ & 3 & 3 & $\mathrm{H}$ & $\begin{array}{l}\text { Inspeksi/pengawasan } \\
\mathrm{K} 3 \text { secara berkala, } \\
\text { safety talks, APD }\end{array}$ & 3 & 2 & $\mathrm{M}$ \\
\hline
\end{tabular}


Tabel 5. Hazard Identification and Risk Assessment (HIRA) (Lanjutan)

\begin{tabular}{|c|c|c|c|c|c|c|c|c|c|c|c|c|}
\hline No & \begin{tabular}{|l|} 
Aktivitas \\
\end{tabular} & Bahaya & Resiko & Acuan & Existing Control & $\mathrm{L}$ & $\mathrm{C}$ & $\mathrm{R}$ & Additional Control & $\mathrm{L}$ & $\mathrm{C}$ & $\mathrm{R}$ \\
\hline \multirow[t]{6}{*}{2} & \multirow[t]{6}{*}{$\begin{array}{l}\text { Proses } \\
\text { penggantian } \\
\text { impeller }\end{array}$} & Radiasi panas & $\begin{array}{l}\text { Cedera, } \\
\text { dehidrasi }\end{array}$ & $\begin{array}{c}\text { SOP } \\
3133 \text { BF33 } 302\end{array}$ & $\begin{array}{l}\text { APD (kacamata } \\
\text { cobalt, helm, } \\
\text { sarung tangan, } \\
\text { masker debu, } \\
\text { seragam jeans) }\end{array}$ & 4 & 2 & $\mathrm{H}$ & $\begin{array}{l}\text { Safety sign, } \\
\text { mematuhi rambu- } \\
\text { rambu safety, } \\
\text { penyediaan air } \\
\text { minum yang cukup }\end{array}$ & 4 & 1 & $\mathrm{M}$ \\
\hline & & $\begin{array}{l}\text { Pekerja } \\
\text { terjatuh }\end{array}$ & Cedera, luka & $\begin{array}{l}\text { UU No. } 1 \\
\text { Tahun } 1970\end{array}$ & $\begin{array}{l}\text { Menggunakan } \\
\text { metode kerja, } \\
\text { awareness } \mathrm{K} 3 \text {, dan } \\
\text { APD }\end{array}$ & 2 & 2 & $\mathrm{~L}$ & & & & \\
\hline & & Debu & $\begin{array}{l}\text { Iritasi mata, } \\
\text { sesak nafas }\end{array}$ & $\begin{array}{c}\text { SOP } \\
3133 \text { BF33 } 302\end{array}$ & $\begin{array}{l}\text { Awareness K3, } \\
\text { APD (respirator } \\
\text { dan masker) }\end{array}$ & 3 & 2 & M & $\begin{array}{l}\text { Inspeksi/pengawasan } \\
\mathrm{K} 3 \text { secara berkala, } \\
\text { pengawasan } \\
\text { penggunaan masker }\end{array}$ & 3 & 1 & $\mathrm{~L}$ \\
\hline & & $\begin{array}{l}\text { Tangan } \\
\text { terjepit }\end{array}$ & $\begin{array}{l}\text { Luka memar, } \\
\text { luka gores }\end{array}$ & $\begin{array}{c}\text { SOP } \\
3133 \text { BF33 } 302\end{array}$ & $\begin{array}{l}\text { APD (sarung } \\
\text { tangan), awareness } \\
\mathrm{K} 3\end{array}$ & 3 & 2 & $\mathrm{M}$ & $\begin{array}{l}\text { Melakukan } \\
\text { pekerjaan sesuai } \\
\text { SOP dengan benar, } \\
\text { safety talks }\end{array}$ & 3 & 1 & L \\
\hline & & $\begin{array}{l}\text { Pekerja } \\
\text { tersandung } \\
\text { benda lain }\end{array}$ & $\begin{array}{l}\text { Terjatuh, } \\
\text { cedera }\end{array}$ & $\begin{array}{c}\text { SOP } \\
3133 \text { BF33 } 302\end{array}$ & $\begin{array}{l}\text { Eliminasi } \\
\text { (merapikan area } \\
\text { kerja) }\end{array}$ & 2 & 2 & $\mathrm{~L}$ & & & & \\
\hline & & $\begin{array}{l}\text { Kabel yang } \\
\text { menghalangi } \\
\text { mobilisasi }\end{array}$ & $\begin{array}{l}\text { Tersandung, } \\
\text { memar }\end{array}$ & $\begin{array}{l}\text { Kepmenaker } \\
75 / \mathrm{MEN} / 2002\end{array}$ & $\begin{array}{l}\text { Eliminasi } \\
\text { (merapihkan kabel) }\end{array}$ & 2 & 1 & $\mathrm{~L}$ & & & & \\
\hline No & Aktivitas & Bahaya & Resiko & Acuan & Existing Control & $\mathrm{L}$ & $\mathrm{C}$ & $\mathrm{R}$ & Additional Control & L & $\mathrm{C}$ & $\mathrm{R}$ \\
\hline \multirow[t]{4}{*}{3} & \multirow[t]{4}{*}{$\begin{array}{l}\text { Proses hot } \\
\text { repair } \\
\text { impeller }\end{array}$} & Radiasi panas & $\begin{array}{l}\text { Cedera, } \\
\text { dehidrasi, luka } \\
\text { bakar }\end{array}$ & $\begin{array}{c}\text { SOP } \\
3133 \text { BF33 } 302\end{array}$ & $\begin{array}{l}\text { Pengaturan kerja, } \\
\text { pengendalian teknis } \\
\text { (eliminasi, } \\
\text { substitusi) }\end{array}$ & 4 & 2 & $\mathrm{H}$ & $\begin{array}{l}\text { Safety sign, } \\
\text { mematuhi rambu- } \\
\text { rambu safety, } \\
\text { penyediaan air } \\
\text { minum yang cukup }\end{array}$ & 4 & 1 & $\mathrm{M}$ \\
\hline & & $\begin{array}{l}\text { Terkena hot } \\
\text { impeller }\end{array}$ & $\begin{array}{l}\text { Tangan } \\
\text { melepuh, luka } \\
\text { bakar ringan }\end{array}$ & $\begin{array}{c}\text { SOP } \\
3133 \text { BF33 } 302\end{array}$ & $\begin{array}{l}\text { APD (baju tahan } \\
\text { api, helm, sarung } \\
\text { tangan, masker } \\
\text { debu.) }\end{array}$ & 3 & 3 & $\mathrm{H}$ & $\begin{array}{l}\text { Inspeksi/pengawasan } \\
\mathrm{K} 3 \text { secara berkala, } \\
\text { safety talks, APD }\end{array}$ & 3 & 2 & $\mathrm{M}$ \\
\hline & & Debu & $\begin{array}{l}\text { Iritasi mata, } \\
\text { sesak nafas }\end{array}$ & $\begin{array}{c}\text { SOP } \\
3133 \text { BF33 } 302\end{array}$ & $\begin{array}{l}\text { Awareness K3, } \\
\mathrm{APD} \text { (respirator } \\
\text { dan masker) }\end{array}$ & 3 & 2 & M & $\begin{array}{l}\text { Inspeksi/pengawasan } \\
\mathrm{K} 3 \text { secara berkala, } \\
\text { pengawasan } \\
\text { penggunaan masker }\end{array}$ & 3 & 1 & L \\
\hline & & $\begin{array}{l}\text { Pekerja } \\
\text { terjatuh dari } \\
\text { exchange car }\end{array}$ & $\begin{array}{l}\text { Cedera, luka- } \\
\text { luka }\end{array}$ & $\begin{array}{c}\text { SOP } \\
3133 \text { BF33 } 302\end{array}$ & $\begin{array}{l}\text { Menggunakan } \\
\text { metode kerja, } \\
\text { awareness } \mathrm{K} 3 \text {, dan } \\
\mathrm{APD}\end{array}$ & 2 & 2 & $\mathrm{~L}$ & & & & \\
\hline No & Aktivitas & Bahaya & Resiko & Acuan & Existing Control & $\mathrm{L}$ & $\mathrm{C}$ & $\mathrm{R}$ & Additional Control & $\mathrm{L}$ & $\mathrm{C}$ & $\mathrm{R}$ \\
\hline \multirow[t]{3}{*}{4} & \multirow[t]{3}{*}{$\begin{array}{l}\text { Proses } \\
\text { cleaning } \\
\text { impeller head }\end{array}$} & $\begin{array}{l}\text { Terkena } \\
\text { percikan hot } \\
\text { metal }\end{array}$ & $\begin{array}{l}\text { Tangan } \\
\text { melepuh, luka } \\
\text { bakar ringan }\end{array}$ & $\begin{array}{c}\text { SOP } \\
3133 \text { BF33 } 302\end{array}$ & $\begin{array}{l}\text { APD (baju tahan } \\
\text { api, kacamata } \\
\text { cobalt, helm, } \\
\text { sarung tangan, } \\
\text { masker debu, } \\
\end{array}$ & 3 & 3 & $\mathrm{H}$ & $\begin{array}{l}\text { Inspeksi/pengawasan } \\
\mathrm{K} 3 \text { secara berkala, } \\
\text { safety talks, APD }\end{array}$ & 3 & 2 & $\mathrm{M}$ \\
\hline & & Debu & $\begin{array}{l}\text { Iritasi mata, } \\
\text { sesak nafas }\end{array}$ & $\begin{array}{c}\text { SOP } \\
3133 \text { BF33 } 302\end{array}$ & $\begin{array}{l}\text { Awareness } \mathrm{K} 3 \text {, } \\
\mathrm{APD} \text { (respirator } \\
\text { dan masker) }\end{array}$ & 3 & 2 & L & $\begin{array}{l}\text { Inspeksi/pengawasan } \\
\mathrm{K} 3 \text { secara berkala, } \\
\text { pengawasan } \\
\text { penggunaan masker }\end{array}$ & 3 & 1 & $\mathrm{~L}$ \\
\hline & & $\begin{array}{l}\text { Pekerja } \\
\text { terkena benda } \\
\text { lain } \\
\end{array}$ & Cedera & $\begin{array}{c}\text { SOP } \\
3133 \text { BF33 } 302\end{array}$ & $\begin{array}{l}\text { Eliminasi } \\
\text { (merapikan area } \\
\text { kerja) }\end{array}$ & 2 & 2 & L & & & & \\
\hline
\end{tabular}


Tabel 5. Hazard Identification and Risk Assessment (HIRA) (Lanjutan)

\begin{tabular}{|c|c|c|c|c|c|c|c|c|c|c|c|c|}
\hline No & Aktivitas & Bahaya & Resiko & Acuan & Existing Control & L & $\mathrm{C}$ & $\mathrm{R}$ & Additional Control & $\mathrm{L}$ & $\mathrm{C}$ & $\mathrm{R}$ \\
\hline \multirow[t]{6}{*}{5} & \multirow[t]{6}{*}{$\begin{array}{l}\text { Proses operasi } \\
\text { manual } \\
\text { temperature } \\
\text { and sampling } \\
\text { device }\end{array}$} & $\begin{array}{l}\text { Terkena } \\
\text { percikan hot } \\
\text { metal }\end{array}$ & $\begin{array}{l}\text { Tangan } \\
\text { melepuh, luka } \\
\text { bakar ringan }\end{array}$ & $\begin{array}{c}\text { SOP } \\
3133 \text { BF33 } 302\end{array}$ & $\begin{array}{l}\text { APD (baju tahan } \\
\text { api, kacamata } \\
\text { cobalt, helm, } \\
\text { sarung tangan, } \\
\text { masker debu, }\end{array}$ & 3 & 3 & $\mathrm{H}$ & $\begin{array}{l}\text { Inspeksi/pengawasan } \\
\mathrm{K} 3 \text { secara berkala, } \\
\text { safety talks, APD }\end{array}$ & 3 & 2 & $\mathrm{M}$ \\
\hline & & Radiasi panas & $\begin{array}{l}\text { Cedera, } \\
\text { dehidrasi, luka } \\
\text { bakar }\end{array}$ & $\begin{array}{c}\text { SOP } \\
3133 \mathrm{BF} 33302\end{array}$ & $\begin{array}{l}\text { Pengaturan kerja, } \\
\text { pengendalian teknis } \\
\text { (eliminasi, } \\
\text { substitusi) }\end{array}$ & 4 & 2 & $\mathrm{H}$ & $\begin{array}{l}\text { Safety sign, } \\
\text { mematuhi rambu- } \\
\text { rambu safety, } \\
\text { penyediaan air } \\
\text { minum yang cukup }\end{array}$ & 4 & 1 & $\mathrm{M}$ \\
\hline & & $\begin{array}{l}\text { Pekerja } \\
\text { tersandung } \\
\text { benda lain }\end{array}$ & $\begin{array}{l}\text { Terjatuh, } \\
\text { cedera }\end{array}$ & $\begin{array}{c}\text { SOP } \\
3133 \mathrm{BF} 33302\end{array}$ & $\begin{array}{l}\text { Eliminasi } \\
\text { (merapikan area } \\
\text { kerja) }\end{array}$ & 2 & 2 & L & & & & \\
\hline & & $\begin{array}{l}\text { Terpeleset } \\
\text { akibat licinnya } \\
\text { lantai kerja }\end{array}$ & Luka, terjatuh & $\begin{array}{c}\text { SOP } \\
3133 \mathrm{BF} 33302\end{array}$ & $\begin{array}{l}\text { Eliminasi } \\
\text { (membersihkan } \\
\text { area kerja) }\end{array}$ & 3 & 2 & $\mathrm{M}$ & $\begin{array}{l}\text { Safety sign, } \\
\text { membersihkan area } \\
\text { kerja }\end{array}$ & 3 & 1 & $\mathrm{~L}$ \\
\hline & & Aliran listrik & Tersetrum & $\begin{array}{l}\text { Kepmenaker. } \\
\text { 75/MEN/2002 }\end{array}$ & $\begin{array}{l}\text { Awareness K3, } \\
\text { safety shoes, sarung } \\
\text { tangan safety }\end{array}$ & 2 & 2 & L & $\begin{array}{l}\text { Safety sign, } \\
\text { Inspeksi/pengawasan } \\
\mathrm{K} 3 \text {, mematuhi } \\
\text { rambu-rambu safety }\end{array}$ & 2 & 3 & $\mathrm{M}$ \\
\hline & & $\begin{array}{l}\text { Kabel yang } \\
\text { menghalangi } \\
\text { mobilisasi }\end{array}$ & $\begin{array}{l}\text { Tersandung, } \\
\text { memar }\end{array}$ & $\begin{array}{c}\text { Kepmenaker } \\
75 / \mathrm{MEN} / 2002\end{array}$ & $\begin{array}{l}\text { Eliminasi } \\
\text { (merapihkan kabel) }\end{array}$ & 2 & 1 & $\mathrm{~L}$ & & & & \\
\hline
\end{tabular}

\section{KESIMPULAN}

Berdasarkan hasil dari analisis yang dilakukan terhadap keseluruhan proses yang adalah bahaya yang terdapat di area produksi hot metal treatment plant divisi blast furnace tergores pisau charging, kejatuhan material, debu, terpeleset akibat licinnya lantai kerja, kabel sling putus, terkena swing, paparan gas, radiasi panas, pekerja terjatuh, tangan terjepit, pekerja tersandung benda lain, kabel yang menghalangi mobilisasi, terkena hot impeller, pekerja terjatuh dari exchange car, terkena percikan hot metal, pekerja terkena benda lain dan aliran listrik. Hasil identifikasi risiko kecelakaan kerja yang dapat terjadi di area hot metal treatment plant adalah 26 risiko yang digolongkan berdasarkan potensi bahaya yaitu 9 risiko masuk dalam kategori high $(\mathrm{H}), 7$ risiko masuk dalam kategori moderate $(\mathrm{M})$ dan sisanya sebanyak 10 risiko masuk dalam kategori low (L). Rekomendasi yang diberikan terhadap perusahaan adalah dengan melakukan mitigasi secara terperinci terhadap risiko kategori high $(\mathrm{H})$ dan kategori moderate $(\mathrm{M})$ sampai level risiko tersebut turun menjadi risiko masuk dalam kategori low (L) sebelum plant blast furnace dioperasikan secara penuh serta memberikan pelatihan terus-menerus terkait K3 untuk tenaga kerja yang disesuaikan dengan kebutuhan jabatan dan fungsi masing-masing, melakukan inspeksi atau pengawasan K3 secara berkala, melakukan safety talks secara rutin kepada semua pekerja, penggunaan APD (alat pelindung diri) yang baik dan benar, pemasangan safety sign, penyediaan air minum yang cukup dan melakukan pekerjaan sesuai SOP.

\section{DAFTAR PUSTAKA}

Alauddin, M. R., Denny, H. M., \& Jayanti, S. (2015). Analisis Hira (Hazard Identification and Risk Assessment) Pada Industri Tahu Serasi Bandungan Baru Semarang. Jurnal Kesehatan Masyarakat (e-Journal), 3(2), 158-167.

Ambarani, A. Y., \& Tualeka, A. R. (2017). Hazard Identification And Risk Assessment (HIRA) Pada Proses Fabrikasi Plate Tanki 42-T501a PT Pertamina (Persero) Ru Vi Balongan. The Indonesian Journal of Occupational Safety and Health, 5(2), 192203.

Kurniawati, E., Sugiono, S., \& Yuniarti, R. (2014). Analisis Potensi Kecelakaan Kerja Pada Departemen Produksi Springbed Dengan Metode Hazard Identification And Risk Assessment (HIRA)(Studi Kasus: PT. Malindo Intitama Raya, Malang, Jawa Timur). Jurnal Rekayasa Dan Manajemen Sistem Industri, 2(1), p11-23.

Panjaitan, N. (2017). Bahaya Kerja Pengolahan Rss (Ribbed Smoke Sheet) Menggunakan Metode Hazard Identification and Risk Assessment di PT. PQR. Jurnal Sistem 
Teknik Industri, 19(2), 50-57.

Ramli, S. (2010). Sistem Manajemen Keselamatan dan Kesehatan Kerja OHSAS 18001. Jakarta: Dian Rakyat.

Restuputri, D. P., \& Sari, R. P. D. (2015). Analisis kecelakaan kerja dengan menggunakan metode Hazard and Operability Study (HAZOP). Jurnal Ilmiah Teknik Industri, 14(1), 24-35.

Sulaksmono, M. (1997). Manajemen Keselamatan Kerja. Surabaya: Penerbit Pustaka.

Supriyadi, S., \& Ramdan, F. (2017). Hazard Identification and Risk Assessment In Boiler Division using Hazard Identification Risk Assessment and Risk Control (HIRARC). Journal of Industrial Hygiene and Occupational Health, 1(2), 161-177.

Suryanti, F., \& Mulyono, M. (2017). Hazard Identification Dan Risk Assessement (HIRA) Pada pengoperasian Forklift Di PT Bangun Sarana Baja Gresik. Jurnal Ilmiah Kesehatan Media Husada, 6(2), 205-214. 